\title{
Comparison of shallot and tobacco farm income in Selopamioro Village, Imogiri Sub District, Bantul District, Yogyakarta
}

\author{
Pujastuti Sulistiyaning Dyah* and Ananto Yahya Putra \\ Department of Agribusiness, Faculty of Agriculture, Universitas Muhammadiyah Yogyakarta, Jl. \\ Brawijaya, Tamantirto, Kasihan, Bantul, D.I. Yogyakarta, Indonesia
}

\begin{abstract}
Indonesia as an agricultural country has two seasons, thereare the dry season and the rainy season. In the dry season they cultivate a lot of palawija crops. Some palawija plants actually have a higher economic value, such as tobacco and shallots. The costs of these two commodities are different, will result in different income. This research objectives is to know the cost, income, and feasibility of tobacco and shallot farming. If shallot farming can be an alternative to replace tobacco, this will encourage a reduction in the cigarette industry in Indonesia. The research was conducted in Selopamioro Village, Imogiri District, Bantul Regency, using purposive sampling technique and 46 farmers as respondents. The income and feasibility analysis uses the measure NR $=\mathrm{TR}-\mathrm{TC}$ and R/C. The results showed that shallot farming, with an average land area of $466 \mathrm{~m}^{2}$, provided a higher income, there is IDR 24,266,482 (2 times planting) compared to tobacco farming of IDR 7,287,396. R/C of shallot farming is 7.99 and tobacco is 12.23 . It can be concluded that shallot farming can be used as an alternative to tobacco farming because it is more profitable.
\end{abstract}

\section{Introduction}

Agriculture is an important sector in development in Indonesia. This is indicated by the large number of labor force absorbed in the agricultural sector reaching $50 \%$ with the condition of most of the farmers including small farmers who only have agricultural land and limited capital so that the results obtained from farming cannot meet their daily needs [1]. Tobacco (Nicotiana spp.L.) is one of the plantation commodities that has an important role in the development of the plantation sector. Various problems faced by tobacco farmers do not cause a decrease in the contribution of tobacco to the economy in Indonesia. This is because the increase in the number of requests for tobacco continues to increase and the increase in the number of exports of tobacco abroad is increasing [2].

The existence of the growing cigarette industry is supported by the presence of tobacco farmers are spread out in several regions in Indonesia. The economic value of tobacco plants is the high-value income group with relatively stable prices because of its clear

* Corresponding author: pujasuti@,umy.ac.id 
market share. Another supporting factor is the condition of the Indonesian people who still like to smoke.

Currently, the existence of cigarettes is starting to be opposed by the community, both the Indonesian people themselves and especially the world community. The World Health Organization (WHO) has discussed in its research the Smoking Control Strategy in Developing Countries. In developed countries smoking is generally understood as a cause of lung cancer, coronary heart disease, chronic bronchitis, and other respiratory disorder. People in most developing countries are unaware of these health hazards, and no educational, legislative, or other steps are being taken to combat the smoking epidemic.

In Indonesia, several strategies to avoid the adverse effects of smoking have been carried out, including the policy of applying cigarette prices, policies to prevent smoking in adolescents, prohibiting smoking in public spaces. This strategy is expected to be able to help people to avoid starting smoking or stop smoking [3].

If the commitment to environmental health is considered important, then the existence of the cigarette industry must be limited and gradually closed, following the issue of the impact caused by cigarette consumption that can damage the environment and damage health.

This attitude against smoking is further strengthened by the international law of the Framework Convention on Tobacco Control (FCTC) in February 2005. This regulation aims to protect the public from the health, environmental and exposure consequences of cigarette smoke [4]. In 2003 the World Health Organization (WHO) issued an agreement to reduce the demand for tobacco products and solve the tobacco problem by reducing production in each country. Countries that sign the agreement including Indonesia should promote an economical alternative to tobacco for farmers [5].

The Indonesian government is currently restricting the production and consumption of processed tobacco products in the form of cigarettes, which is stated in Law No. 36 of 2009 concerning health, which states that nicotine is an addictive substance that can endanger health. In addition, there is also a Government Regulation, namely PP No. 109 of 2012 concerning the safety of materials containing addictive substances in the form of tobacco products for health [1].

Indeed, the health problems associated with smoking cigarettes are related to the level of education. Developed countries are first serious in dealing with the dangers of smoking. According to [6] the cigarette industry in Indonesia is considered to be growing rapidly. According to the Ministry of Trade's records, the Indonesian cigarette industry grows by $10 \%$ every year. This study uses Five Forces Analysis, which consists of the threat of new entrants, the threat of substitute products, the bargaining power of suppliers, the bargaining power of buyers, and competition between companies, about 1.1 billion people aged 15 years and over smoke, $80 \%$ of whom live in low- and middle-income countries (LMICs). This fact shows that tobacco growth and consumption has concentrated in developing countries where the health, economic and environmental burdens are the heaviest and there is a tendency to increase without strict enforcement of tobacco controls. Smoking in developing countries has been shown to reinforce poverty.

According to [7] the cigarette industry in Indonesia is considered to be growing rapidly. According to the Ministry of Trade's records, the Indonesian cigarette industry grows by $10 \%$ every year. This study uses Five Forces Analysis, which consists of the threat of new entrants, the threat of substitute products, the bargaining power of suppliers, the bargaining power of buyers, and competition between companies.

Indonesia is one of the 15 countries listed as exporters of tobacco cigarettes. Global cigarette shipments exported by these countries in 2019 reached $79.9 \%$, and Indonesia was in 5th place contributing $4.4 \%$ [8]. 
In 2000, about a third (33.3\%) of the global population (both sexes combined) and 15 years old and older, are current users of some forms of tobacco. By 2015, this rate had decreased to approa quarter $(24.9 \%)$ of the global population. Assuming that current efforts in tobacco control are maintained in all countries, the figure is projected to decline further to about one-fifth $(20.9 \%$ ) of global population by 2025 (WHO global report on trends in prevalence of tobacco use 2000-2025 third edition) [9].

Several developed countries that have implemented tobacco consumption control have succeeded in reducing the level of cigarette consumers. In 2000, about a third (33.3\%) of the global population aged 15 years or older were users at that time. This rate decreased, in 2015 , to $24.9 \%$ of the global population. It is projected that by 2025 the figure will decline further to $20.9 \%$ of the global population (WHO global report on trends in prevalence of tobacco use 2000-2025, third edition ISBN 978-92-4-000003-2)[9].

Because the prospect of tobacco plants is no longer recommended, it is necessary to look for other alternatives for farmers to be able to choose other plants that have at least the same economic value as tobacco plants.

Bantul Regency is one of the regions in DIY that relies on tobacco commodities with a tobacco land area of 172 hectares with a total production of $1,023.50$ quintals [10]. Tobacco farming activities are spread in several areas in Bantul Regency. The following is data on land area and production by sub-district in Bantul Regency.

Table 1. Land area and production of tobacco plants in Bantul Regency, Yogyakarta 2015-2016

\begin{tabular}{|c|l|r|r|}
\hline No & \multicolumn{1}{|c|}{ Districts } & Land area (hectares) & Production (quintal) \\
\hline 1 & Srandakan & - & - \\
\hline 2 & Sanden & - & - \\
\hline 3 & Kretek & - & - \\
\hline 4 & Pundong & - & - \\
\hline 5 & Bambanglipuro & - & - \\
\hline 6 & Pandak & - & - \\
\hline 7 & Bantul & - & - \\
\hline 8 & Jetis & $\mathbf{1 0 0 . 0 0}$ & - \\
\hline $\mathbf{9}$ & Imogiri & 20.00 & $\mathbf{5 7 4 . 8 0}$ \\
\hline 10 & Dlingo & 50.00 & 122.00 \\
\hline 11 & Pleret & 2.00 & 325.00 \\
\hline 12 & Piyungan & - & 1.70 \\
\hline 13 & Banguntapan & - & - \\
\hline 14 & Sewon & - & - \\
\hline 15 & Kasian & - & - \\
\hline 16 & Pajangan & - & - \\
\hline 17 & Sedayu & 172.00 & $1,023.50$ \\
\hline & Total & & \\
\hline
\end{tabular}

Source: [10]

The largest tobacco producer in Bantul Regency is in Imogiri District. Tobacco is grown in the dry season. The following is data on land area and production of shallot by subdistrict in Bantul Regency Table 2. 
Table 2. Land area and production of shallots in Bantul Regency, Yogyakarta in 2017.

\begin{tabular}{|l|l|r|r|}
\hline No & \multicolumn{1}{|c|}{ Districts } & \multicolumn{1}{|c|}{$\begin{array}{c}\text { Land area } \\
\text { (hectares) }\end{array}$} & \multicolumn{2}{c|}{$\begin{array}{c}\text { Production } \\
\text { (quintal) }\end{array}$} \\
\hline 1 & Srandakan & 1 & 75 \\
\hline 2 & Sanden & 138 & 10,265 \\
\hline 3 & Kretek & 383 & 452 \\
\hline 4 & Pundong & 0 & 0 \\
\hline 5 & Bambanglipuro & 0 & 0 \\
\hline 6 & Pandak & 1 & 69 \\
\hline 7 & Bantul & 0 & 0 \\
\hline 8 & Jetis & $\mathbf{2 2 4}$ & $\mathbf{2 7 , 1 4 3}$ \\
\hline $\mathbf{9}$ & Imogiri & 2 & 96 \\
\hline 10 & Dlingo & 0 & 0 \\
\hline 11 & Pleret & 0 & 0 \\
\hline 12 & Piyungan & 0 & 0 \\
\hline 13 & Banguntapan & 0 & 0 \\
\hline 14 & Sewon & 0 & 0 \\
\hline 15 & Kasihan & 0 & 75 \\
\hline 16 & Pajangan & 2 & 52,951 \\
\hline 17 & Sedayu & 757 & 0 \\
\hline & Total Number & & 0 \\
\hline
\end{tabular}

The reason farmers grow tobacco is because this commodity is easy to maintain and has stable demand. Besides tobacco, there are several farmers who grow shallots in the same season. Shallots are a commodity that also has a high economic value and a short growing period. The demand for shallots is also stable because this commodity is needed every day as a cooking spice.

The cost of these two commodities is different, will produce different income. Which is more profitable for farmers, the aim of this study is to find out the costs, income, and feasibility of tobacco and shallot farming. If onion farming can be an alternative to replace tobacco, this will push the reduction of the cigarette industry in Indonesia. The income and feasibility analysis uses the measures $\mathrm{NR}=\mathrm{TR}-\mathrm{TC}$ and $\mathrm{R} / \mathrm{C}$.

(Q: Quantity; $\mathrm{P}_{\mathrm{Q}}$ : Price of production)

$$
\text { Note: } T R(\text { Total Revenue })=Q \times P_{Q}
$$

$$
\text { TC }(\text { Total Cost })=Y \times H_{Y}
$$

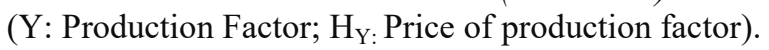

\section{Research methods}

This research was done in Selopamioro Village, Immogiri District, Bantul Regency. Sampling was carried out purposively, that is a deliberate sampling technique with the consideration that Selopamioro Village has the largest number of farmer groups. The number of respondents was 46 farmers using Simple Random Sampling. The data collection technique for primary data collection used the interview method with the help of a questionnaire, while the secondary data was obtained from the Central Statistics Agency (BPS). This study uses a descriptive analysis of income and eligibility using measures of $\mathrm{NR}=\mathrm{TR}-\mathrm{TC}$ and $\mathrm{R} / \mathrm{C}$. 


\section{Results and discussion}

\subsection{Shallot farming}

Shallot farming is planted in the dry season from February to early April. The area of land for this shallot farming was $455 \mathrm{~m}^{2}$. The production period was 2 months and calculation with land conversion of $500 \mathrm{~m}^{2}$.

\subsubsection{Onion farming costs}

The cost of onion farming consists of the cost of production facilities, labor outside the family (TKLK), depreciation of equipment and other costs (this is land tax fee) used during the farming process.

Table 3. Production costs of shallot farming in Kalidadap II Hamlet in 2017.

\begin{tabular}{|r|l|r|r|}
\hline No & \multicolumn{1}{|c|}{ Description } & \multicolumn{2}{c|}{ Cost (IDR) } \\
\hline 1 & Production Facilities & $\mathbf{5 4 . 7 7}$ & $1,044,773$ \\
\hline & Seeds & 6.30 & 120,162 \\
\hline & Manure & 4.44 & 84,710 \\
\hline & ZA fertilizer & 3.51 & 66,948 \\
\hline & Phonska (NPK fertilizer) & 6.27 & 119,548 \\
\hline & TS fertilizer & 3.53 & 67,319 \\
\hline & Liquid pesticide & 5.54 & 105,589 \\
\hline & Solid pesticide & $\mathbf{8 4 . 3 7}$ & $\mathbf{1 . 6 0 9 . 2 4 0}$ \\
\hline & Total Production Facilities & \multicolumn{2}{|c|}{} \\
\hline 2 & TKLK (Outside worker) & 2.78 & 53,034 \\
\hline & Land preparation & 0.92 & 17,558 \\
\hline & Planting & 0.50 & 9,675 \\
\hline & Fertilization & 3.23 & 61,633 \\
\hline & Harvest & $\mathbf{7 . 4 4}$ & 141,901 \\
\hline & Total Outside Workers & & 9,933 \\
\hline 3 & Tool Shrinkage & 0.52 & 3,077 \\
\hline & Hoe & 1.61 & 64,490 \\
\hline & Sickle & 3.38 & 3,936 \\
\hline & Slang & 0.21 & 7,662 \\
\hline & Bucket & 0.40 & 1,870 \\
\hline & Water sprayer & 0.10 & 90,971 \\
\hline & Water pump & $\mathbf{4 . 7 7}$ & 65,623 \\
\hline & Total Tool Shrinkage & $\mathbf{3 . 4 4}$ & $\mathbf{1 , 9 0 7 , 4 5 0}$ \\
\hline 4 & Additional costs & $\mathbf{1 0 0}$ & \\
\hline & Total Explicit cost & & \multicolumn{2}{|c|}{} \\
\hline & \multicolumn{3}{|c|}{} \\
\hline
\end{tabular}

The total explicit cost of onion farming was IDR 1,907,450 with the largest cost component in the cost of production facilities which is dominated by the cost of seeds of IDR 1,044,673 for a land area of $500 \mathrm{~m}^{2}$. The need for shallot seeds is obtained from the previous harvest, which is set aside, so that if the previous harvest has decreased production, for example due to the influence of a bad season, it will affect the supply of seeds for the next season. 


\subsubsection{Sallot farming income}

Table 4. Shallot Farming Income in Kalidadap II Hamlet in 2017.

\begin{tabular}{|l|r|}
\hline \multicolumn{1}{|c|}{ Description } & Amount \\
\hline Production (kg) & 699.96 \\
\hline Price (IDR/kg) & 21,773 \\
\hline Gross income (IDR) & $15,240,229$ \\
\hline Total Explicit cost (IDR) & $1,907,450$ \\
\hline \multicolumn{1}{|c|}{ Income } & $13,333,231$ \\
\hline
\end{tabular}

The income received from shallot farming of IDR 13,333,231 with of cost sacrifice total cost explisit IDR 1,907,450.

\subsection{Tobacco farming}

Tobacco farming is planted from May to August, the production period is 4 months. Cultivated land area of tobacco farmers $466 \mathrm{~m}^{2}$. Calculation with land area conversion of $500 \mathrm{~m}^{2}$.

\subsubsection{Explicit costs of tobacco farming}

These costs include the cost of production facilities, labor costs outside the family (TKLK), depreciation costs, and other costs.

Table 5. Cost of tobacco farming in Kalidadap Hamlet in 2017.

\begin{tabular}{|l|r|}
\hline \multicolumn{1}{|c|}{ Description } & Amount (IDR) \\
\hline Production Facility Cost & 395,855 \\
\hline Outside workers & 156,746 \\
\hline Tool shrinkage & 78,143 \\
\hline Additional costs & 65,240 \\
\hline Total Explicit Cost & $\mathbf{6 8 5 , 2 5 4}$ \\
\hline
\end{tabular}

The total explicit costs incurred by tobacco farming are IDR 685,254 which is dominated by the cost of production facilities.

\subsubsection{Tobacco farming income}

Table 6. Tobacco farming income in Kalidadap II Hamlet in 2017.

\begin{tabular}{|l|r|}
\hline \multicolumn{1}{|c|}{ Description } & \multicolumn{1}{c|}{ Amount (IDR) } \\
\hline Production (kg) & 105.12 \\
\hline Price (IDR/kg) & 81,016 \\
\hline Gross income (IDR) & $8,515,079$ \\
\hline Total Explicit Cost (IDR) & 685,254 \\
\hline \multicolumn{1}{|c|}{ Income } & $\mathbf{7 , 8 1 9 , 0 9 4}$ \\
\hline
\end{tabular}

Tobacco farming income is the income earned by farmers from tobacco farming per planting period from May to August. The income received from tobacco farming is IDR $7,819.094$ with of cost sacrifice total cost explicit IDR 685,254. 


\subsubsection{Alternative to tobacco farming}

To be able to determine alternatives to tobacco farming, it is necessary to know what is being cultivated in the same season. Shallot farming is planted for 2 months from the end of February to April. Meanwhile, tobacco farming is planted for 4 months from May to the end of August. This means that shallot and tobacco farming are planted in the same season, that is the dry season.

To compare the costs and income of the two farms, the planting time period and land area must be converted. With the conversion of a land area of $500 \mathrm{~m} 2$ the results are as shown in Table 6 below.

Table 7. Costs and Income of Shallot and Tobacco Farming.

\begin{tabular}{|l|r|r|}
\hline \multicolumn{1}{|c|}{ Description } & \multicolumn{1}{c|}{ Tobacco } & \multicolumn{1}{c|}{ Sallot } \\
\hline Cost (IDR) & 685,254 & $1,907,450$ \\
\hline Gross income (IDR) & $8,515,079$ & $15,240,229$ \\
\hline Income (IDR) & $7,819,094$ & $13,333,231$ \\
\hline R/C (\%) & $1,242.62$ & 798.98 \\
\hline
\end{tabular}

The costs incurred for shallot farming are much greater than the costs of tobacco farming. However, the income obtained from the shallot farming is also greater than the income from the tobacco farming. The $\mathrm{R} / \mathrm{C}$ of tobacco farming is greater than that of shallots, which means that the cost efficiency is more profitable for tobacco. But for farmers, of course, prioritize the amount of income over the amount of capital productivity, especially the land owned by farmers is limited.

The shallot farming can be planted 2 times later in the same season. Because there is no cost and production data on the 2 nd shallot plant, it is assumed that the data on the next 2 months crop in early April-May is the same in terms of cost and production usage, which is still in the same season, that is the dry season, so that if the income earned is doubled, it becomes IDR 26,666,462 which is much greater than the tobacco income of IDR 7,819,094 and can only plant once because it takes 4 months in the dry season. This means that in terms of income, the alternative that can replace tobacco farming in Selopamioro Village is onion farming. In terms of production costs, farmers must be able to provide more costs, but these costs will be returned for only 2 months, then farmers can plant them again after harvesting, and the next two months are still in the dry season. So far, some farmers choose to plant tobacco due to several factors.

According to [11] several factors become obstacles in replacing tobacco, that is technically tobacco plants have advantages in dry land and climates. Economically, tobacco commodities have a relatively high level of farm income and not many commodities match that level of income even though they have a high degree of risk as well.

The stability of demand and price stability may be the cause. The tobacco market is more stable in line with the steady demand of the cigarette industry. Meanwhile, shallot farming is more speculative, when the price soars, the income is very large, but when the price falls, it can be a loss. The price of shallots when they are low reaches an average of IDR $15,000 / \mathrm{kg}$ and when prices are high, they can reach IDR $85,000 / \mathrm{kg}$. In fact, the demand for this shallot commodity is relatively stable because it is a product that is needed every day as a cooking spice in Indonesia. However, this shallot commodity cannot be stored for long because of its perishable nature.

Because there are still many farmers who grow tobacco compared to planting shallots with 2 time later, further research is needed on what are the factors that cause farmers to prefer to plant tobacco and not choose to plant shallots with 2 times later in the same season. 
Related with the need for production costs of onion farming, so that farmers can switch to replacing tobacco farming into shallots, it is the government's task to overcome these obstacles, that is production financing problems, and price stability.

\section{Conclusion}

The amount for shallot farming per $500 \mathrm{~m}^{2}$ land area is IDR 1,907,450 with an income of IDR 13,333,231 with a land area of $500 \mathrm{~m}^{2}$ and a production period of 2 months. While the costs for tobacco farming per $500 \mathrm{~m}^{2}$ land area is IDR 685,254 with an income of IDR7,819,094 with a land area of $500 \mathrm{~m}^{2}$ and a production period of 4 months.

Tobacco farming and shallot farming Selopamioro Village, Imogiri Sub-District, Bantul District, Yogyakarta are both feasible, with different feasibility ratios. Shallot farming can be an alternative to replace tobacco farming in Selopamioro Village, Imogiri District, Bantul Regency, because this is more profitable from the financial calculation and human health.

\section{References}

1. S. Astuti Y, J. Bumi Indones. 1, (2012).

2. Fauziyah, J. Organ. Dan Manaj. 6, 199 (2010).

3. F. Nurwidya, F. Takahashi, H. Baskoro, M. Hidayat, F. Yunus, and K. Takahashi, Epidemiol. Health (2014).

4. H. Putra, A. Muhaimin, and S. Suhartini, HABITAT (2015).

5. T. W. Hu and A. H. Lee, J. Public Health Policy (2015).

6. ASH, ASH Fact Sheet: Tobacco and the Developing World (2019) (2019).

7. S. N. N. Karinka Aurelie, Meyer Nicholas, Nusant. J. Curr. Econ. Bus. Ventur. 1, 1 (2021).

8. Daniel Workman, (2021).

9. O. M. da S. OMS, World Health. Organ. (2015).

10. BPS, BPS Bantul Dalam Angka (Bantul, Yogyakarta, 2016).

11. M. Rachmat and S. Nuryanti, Forum Penelit. Agro Ekon. (2016). 